\title{
Apropriasi Rumah Tradisional Batak Toba pada Arsitektur Gereja Katolik Pangururan di Samosir
}

\section{Appropriation of Batak-Toba Traditional Houses in the Architecture of the Pangururan Catholic Church in Samosir}

\author{
Ronald Hasudungan Irianto Sitindjak \\ Program Studi Desain Interior, Fakultas Seni dan Desain, Universitas Kristen Petra \\ Alamat: Jalan Siwalankerto, Kecamatan Wonocolo, Surabaya, Indonesia 60236 \\ E-mail: ronald_his@petra.ac.id
}

\begin{abstract}
Abstrak
Artikel ini fokus pada bentuk apropriasi rumah tradisional Batak-Toba pada arsitektur Gereja Katolik. Apropriasi budaya adalah penggunaan simbol budaya, artefak, genre, ritual, atau teknologi oleh anggota budaya lain, dimana unsur-unsur tersebut dipilih melalui proses penyesuaian agar akhirnya dapat diterima menjadi hak milik, tanpa keharusan memproduksi bentuk yang baru. Bentuknya dapat berupa pertukaran budaya, dominasi budaya, eksploitasi budaya ataupun berupa transkulturasi. Bentuk apropriasi ini dapat dijumpai pada bentuk arsitektural dari Gereja Katolik Pangururan yang terletak di pulau Samosir, daerah asalnya budaya Batak Toba. Metode penelitian bersifat kualitatif dengan pendekatan etnografi. Data diperoleh melalui observasi lapangan, dokumentasi visual, wawancara dan ekplorasi pustaka. Proses analisis data mengaitkan temuan dari lapangan dengan kajian hasil eksplorasi pustaka terkait rumah tradisional Batak Toba. Hasil yang diperoleh, menunjukkan bahwa terdapat konsep-konsep dari rumah tradisional Batak Toba yang diadopsi oleh gereja Katolik, dan diimplementasikan pada bentuk arsitektural Gereja Katolik Pangururan. Apropriasi itu terlihat pada konsep wujud bangunan, ornamen ragam hias, posisi bangunan dan orientasi bangunan dari Gereja Katolik Panguruan. Apropriasi ini memperkaya budaya gereja Katolik dan budaya Batak Toba secara bersamaan. Dalam hal ini proses apropriasi memberi keuntungan bagi kedua budaya yang bertemu.
\end{abstract}

Kata kunci: Apropriasi, Ruma, Batak Toba, Bentuk Arsitektural, Gereja Katolik

\begin{abstract}
This article focused on the appropriation of Batak-Toba traditional houses in architecture of the Catholic Church. Cultural appropriation is the use of cultural symbols, artifacts, genres, rituals, or technology by members of other cultures in which these elements are selected through a process of adjustment so that they can be accepted as property rights, without having to produce new forms. It can take the form of cultural exchange, cultural domination, cultural exploitation or transculturation. The objective of this research is to discover the cultural appropriation found in the architectural form of the Pangururan Catholic Church, located on the island of Samosir, the Batak Toba culture's area of origin. It used the qualitative research method with an ethnographic approach. Data were obtained through field observations, visual documentation, interviews and literature exploration. Meanwhile, the analysis process linked the findings from the field with a study of the results of literature exploration related to the Toba Batak traditional house (Ruma). Findings revealed that there were concepts from the traditional Batak Toba house adopted by the Catholic church and implemented in the architectural form of the Pangururan Catholic Church. The appropriation could be seen in the concept of building form, decorative ornaments, building position and building orientation of the Panguruan Catholic Church. This appropriation has enriched the culture of the Catholic church and the Batak Toba culture simultaneously. In this case the appropriation process has benefitted the two cultures that have met.
\end{abstract}

Keywords: Appropriation; Ruma; Batak Toba; Architectural Form, Catholic Church 
Biokultur, 2020, 9 (2): 87-100. DOI: http://dx.doi.org/10.20473/bk.v9i2.23118.

Article History:

Received November 9, 2020; Accepted November 19, 2020; Published Online November 20, 2020

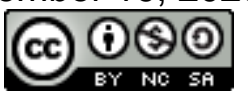

\section{Pendahuluan}

Perjumpaan budaya Batak Toba dan budaya Katolik terlihat mulai dari liturginya, musiknya, sampai pada desain arsitekturalnya. Salah satunya yaitu pada Gereja Katolik Pangururan, di Kabupaten Samosir, Provinsi Sumatera Utara. Gereja ini terletak di jalan Putri Lopian, Pangururan, ibukota Kabupaten Samosir. Bentuk arsitektural gereja ini secara visual menyerupai rumah tradisional Batak Toba. Kemiripan visual ini menyiratkan apropriasi dari budaya Batak Toba pada bentuk arsitektural Gereja Katolik. Hal inilah yang menarik untuk dikaji lebih lanjut.

Gereja Katolik mengambil sikap terbuka dengan budaya Batak Toba. Hal ini menyebabkan terjadinya proses sosial berupa perjumpaan antar budaya. Hal ini sejalan dengan dekrit yang ditetapkan oleh Paus sebagai pimpinan tertinggi gereja Katolik sedunia. Pada Konsili Vatikan II mengenai dekrit tentang kegiatan misioner gereja, ada beberapa pasal yang secara khusus mendukung bahkan mendorong pembangunan Gereja Katolik lokal, yaitu:

\section{Ad Gentes 10:}

"Gereja harus masuk ke dalam semua kelompok budaya dengan maksud yang sama seperti Kristus sendiri, demi penjelmaan-Nya, telah mengikatkan diri pada keadaan sosial budaya khas manusia, bersama siapa Dia hidup".

Ad Gentes 22:

"Gereja lokal menduduki tempatnya dalam persekutuan gereja, hanya kalau gerejagereja tersebut menghiasi diri dengan tradisinya dan menunjukkan identitasnya sebagai gereja lokal".

(Sumber: Ad Gentes: Decree on The Mission Activity of The Church).

Apropriasi atau apropriation dalam Merriam-Webster's Collegiate Dictionary (2004) berarti "untuk mengambil kepemilikan eksklusif dari", dan "untuk mengambil atau memanfaatkan tanpa otoritas atau hak". Apropriasi berasal dari bahasa Latin appropriare, yang berarti "menjadikan milik sendiri", dari akar bahasa Latin proprius yang berarti memiliki, juga akar kepemilikan. Makna ini sejalan dengan penggunaan istilah dalam konteks hukum, memperkuat konotasi pengambilan yang tidak adil atau tidak sah, yaitu pencurian (Rogers 2006).

Dalam perspektif sejarah, perjumpaan antara pihak kolonial dan terkolonialisasi diwarnai penerapan rust en orde (keamanan dan ketertiban). Mengikuti pandangan Antonio Gramsci, dalam perjumpaan tersebut tidak hanya berlangsung pemaksaan (force), melainkan juga persetujuan (consent) terbentuk ketika subjek-subjek dari kedua belah pihak saling memanfaatkan perjumpaan mereka bagi kepentingan masing-masing atau kepentingan bersama (Budrianto, 2018). Pemanfaatan semacam itu disebut dengan istilah 
apropriasi, yaitu pemilihan dan penyesuaian unsur asing dengan ukuran sendiri agar unsur tersebut dapat diterima menjadi hak milik (Barendregt 2016).

Helene Shugart dalam Rogers (2006) mengemukakan apropriasi secara eksplisit sebagai berikut:

"Secara teknis, apropriasi retoris mengacu pada setiap contoh di mana cara yang umumnya terkait dengan dan / atau dianggap sebagai milik orang lain digunakan untuk mencapai tujuan seseorang. Setiap contoh di mana suatu kelompok meminjam atau meniru strategi kelompok lain — bahkan ketika taktik tersebut tidak dimaksudkan untuk mendekonstruksi atau mendistorsi makna dan pengalaman kelompok lain — dengan demikian akan dianggap sebagai apropriasi."

Hal ini membawa Rogers (2006) pada suatu pengertian apropriasi yang lebih luas sebagai penggunaan simbol budaya, artefak, genre, ritual, atau teknologi oleh anggota budaya lain. Apropriasi budaya dapat ditempatkan ke dalam empat kategori, yaitu: 1) pertukaran budaya, yaitu pertukaran secara timbal balik; 2) dominasi budaya yaitu penerapan budaya dominan pada budaya bawahan; 3) eksploitasi budaya yaitu mengambil budaya bawahan untuk manfaat budaya dominan; dan 4) transkulturasi yaitu pencampuran aneka budaya yang tidak bisa disamakan lagi dengan budaya asalnya, sebuah pengembangan hibrida budaya. Transkulturasi menempatkan budaya sebagai fenomena relasional yang dibentuk oleh tindakan apropriasi, bukan entitas yang hanya berpartisipasi dalam apropriasi.

James O. Young (2010) juga menambahkan, apropriasi tidak dapat disamakan dengan manipulasi, karena konsep ini meletakkan penilaian pada konteks pelaku apropriasi, bukan pada konteks budaya sumber. Dengan demikian, apropriasi dapat dilakukan oleh kedua budaya yang berinteraksi, tanpa mengasumsikan perlunya bentuk baru yang dapat diterima kedua pihak.

Menurut Hera S. Walker (1998), integrasi elemen asing ke dalam sebuah kebudayaan secara sadar, adalah sebuah proses perkembangan yang bertahap. Perkembangan itu terjadi bila ada alasan yang cukup untuk diterima oleh budaya pengadopsi. Kutipannya atas Schrieke menerangkan bahwa selama masih di bawah naungan matahari yang sama, tidak ada kebaruan, yang baru merupakan kombinasi pengetahuan. Sebuah penemuan tidak dibuat dari ketiadaan, tetapi berakar dari pengetahuan sebelumnya. Menurut Abdurrahman (2018), kutipan Walker tersebut memunculkan pemahaman bagaimana sebuah kebudayaan berkembang karena adanya kombinasi unsur asli dan asing. Elemen lokal masih diperlukan untuk bisa diterima integrasinya dengan elemen asing yang diadopsinya, termasuk di dalamnya mitos, legenda, dan cerita kepahlawanan yang berkembang pada kebudayaan tertentu.

Apropriasi budaya merupakan salah satu mekanisme pengadopsian beberapa elemen budaya tertentu oleh kelompok budaya yang berbeda. Hal ini menggambarkan adanya proses akulturasi atau asimilasi, akan tetapi dapat menyiratkan pandangan negatif terhadap akulturasi dari budaya minoritas oleh budaya yang dominan. Proses ini dapat mencakup pengenalan bentuk pakaian atau perhiasan, musik dan seni, agama, bahasa, atau perilaku sosial. Unsur-unsur tersebut 'dihapus' dari budaya aslinya, yang melekat adalah transformasi makna yang secara signifikan berbeda dari keberadaanya sejak awal. 
Praktek apropriasi budaya melibatkan 'perampasan' ide, simbol, artefak, gambar, suara, benda, bentuk atau gaya dari budaya lain, dari sejarah seni, budaya populer atau aspek lain yang melekat pada budaya visual maupun non-visualnya (Abdurrahman 2018).

Apropriasi budaya telah dikonsep ulang menjadi pemahaman mengenai relasi radikal yang dialogis. Melalui konsep pemikiran hibriditas, apropriasi transkultural dipahami melalui kondisi historis yang spesifik, membaca fenomena dialektika transnasional dan transkultur sebagai bagian dari konsekuensi globalisasi budaya. Transkulturasi melibatkan elemen-elemen dan bentuk budaya dari berbagai sumber tanpa mengenal batasan ruang dan waktu yang berinteraksi satu sama lain memproduksi bentuk baru dan merubah konvensi budaya yang sedang berjalan (Abdurrahman 2018).

Dari berbagai pengertian diatas, dapat disimpulkan apropriasi adalah pengadopsian elemen budaya tertentu oleh kelompok budaya yang berbeda, berupa penggunaan simbol budaya, artefak, genre, ritual, atau teknologi, dimana unsur-unsur tersebut dipilih melalui proses penyesuaian/adaptasi oleh kedua budaya yang berinteraksi, agar akhirnya dapat diterima menjadi hak milik, tanpa keharusan memproduksi bentuk baru yang dapat diterima kedua pihak.

Dari berbagai pengertian tersebut, dapat disimpulkan apropriasi adalah penggunaan simbol budaya, artefak, genre, ritual, atau teknologi oleh anggota budaya lain, dimana unsur-unsur tersebut dipilih melalui proses penyesuaian agar akhirnya dapat diterima menjadi hak milik, tanpa keharusan memproduksi bentuk yang baru.

\section{Metode}

Penelitian ini merupakan penelitian kualitatif, dan menggunakan pendekatan metode etnografi. Pengumpulan data lapangan berupa dokumentasi visual dari bangunan Gereja Katolik Pangururan (GKP) diperoleh melalui observasi lapangan. Untuk memperoleh data non fisiknya melalui wawancara mendalam dengan pimpinan dan rohaniawan GKP. Data lapangan disajikan secara deskriptif. Selain itu dilakukan juga penelusuran data melalui studi pustaka terkait budaya Batak Toba, khususnya arsitektur tradisional Batak Toba. Proses analisis mengaitkan hasil temuan lapangan dengan studi pustaka terkait rumah tradisional Batak Toba. Analisis untuk menemukan apropriasi dari rumah tradisional Batak Toba pada bentuk arsitektural Gereja Katolik Pangururan. Kemudian simpulan akan disusun secara induktif.

\section{Hasil dan Pembahasan}

Agama Katolik di Indonesia adalah hasil dari kolonialisme Barat. Agama ini masuk ke Sumatera Utara dan mendirikan stasi pertamanya di Medan (daerah tanah Melayu dan tanah Batak Toba) pada tahun 1878. Stasi ini dipimpin oleh pastor C. Wenneker (van den End 2000). Perkembangan berikutnya pada tahun 1914, agama Katolik ini tiba di tanah Batak (Prier 1999; van den End 2000).

Pembangunan gereja ini dipimpin oleh Pastor Leo Joosten, OFM Cap., seorang pastor Belanda. Sedangkan arsiteknya ada dua, yaitu Bruder Anianus Snik, OFM Cap., seorang Belanda yang bertanggung jawab untuk masalah konstruksi bangunannya, dan Toga 
Nainggolan, seorang Batak Toba, yang bertanggung jawab sebagai arsitek tradisional Batak Toba. Pembangunan gereja berlangsung dari tahun 1994 - 1997. Menghabiskan dana kurang lebih delapan ratus juta rupiah, yang berasal dari swadaya jemaat, instansi gereja, baik dalam maupun luar negeri, serta sumbangan pribadi (para donatur).

Bentuk gereja dan rumah Batak Toba dapat dilihat pada gambar berikut:

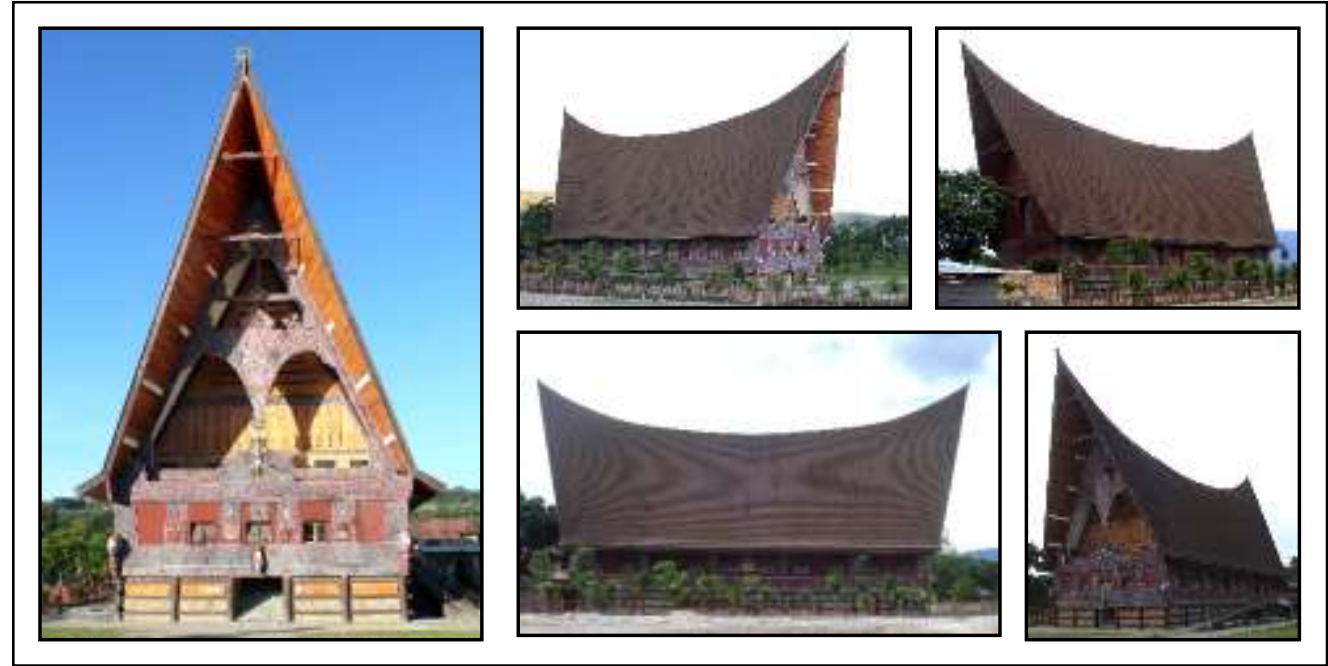

Gambar 1. Gereja Katolik Santo Mikael Pangururan Sumber: Dokumentasi Pribadi, 2011

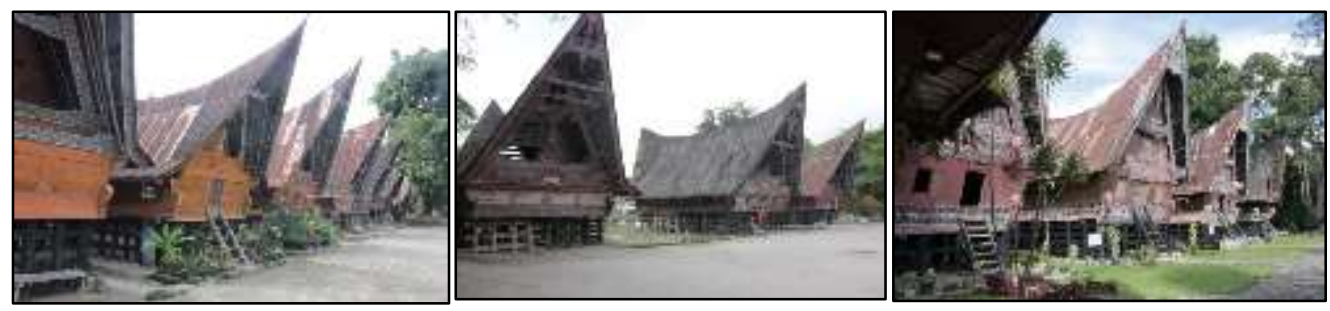

Gambar 2. Dari kiri ke kanan: Rumah Tradisional Batak Toba di Huta Siallagan-Samosir, Huta Bolon Simanindo-Samosir, dan Museum Batak Balige-Toba

Sumber: Dokumentasi Pribadi, 2018-2019

Bentuk arsitektural gereja ini secara visual menyerupai rumah tradisional Batak Toba. Seperti diungkapkan oleh Pastor Togar Herman Nainggolan (6 April 2011):

"Dengan panjang 40 meter dan lebar 16,5 meter, bangunan gereja itu langsung memancarkan kebesaran, mungkin juga keagungan (bukan kesombongan), dibanding dengan bangunan-bangunan lain di sekitarnya. Kesan semacam itu makin diperkuat dengan tingginya yang mencapai 33 meter di bagian depan dan 35 meter di bagian belakang. Perbedaan tinggi ini adalah pemetikan dari bentuk bangunan Rumah Parsaktian, Rumah Adat, yang memang dengan kandungan makna tertentu. Di samping itu, bentuk atas yang melengkung dan dinding tembok yang miring tetap mengambil corak dan wujud Rumah Parsaktian."

\section{Ruma Batak Toba}

Rumah tradisional Batak Toba sering juga disebut Ruma, umumnya berada dalam suatu perkampungan yang disebut Huta. Pola Huta pada umumnya adalah mengelompok. Kelompok bangunan dalam suatu Huta umumnya dua baris. Satu baris terdiri atas deretan Ruma dan baris lain berisi deretan lumbung (Sopo) yaitu selain tempat menyimpan padi, 
juga untuk tempat menenun, menganyam, dan tempat tidur serta berkumpulnya anak lakilaki yang sudah akil balik namun belum menikah. Barisan deretan Ruma umumnya menghadap ke arah gunung atau bukit. Hal ini terkait dengan kepercayaan orang Batak Toba, bahwa disanalah bersemayam Mulajadi Nabolon (Tuhan atau dewa pencipta) dan roh-roh nenek moyang mereka. Kedua barisan bangunan dipisahkan oleh pelataran lebar yang disebut halaman (Alaman), tempat bermain anak-anak, tempat melaksanakan acaraacara adat baik yang bernuansa sukacita maupun dukacita, dan tempat menjemur bahanbahan makanan seperti padi dan jagung (Napitupulu 1997). Tiap Huta dihuni oleh satu keluarga dari satu turunan marga yang sama. Tiap Huta punya pemimpin, biasanya orang yang paling dituakan dari marga pemilik Huta. Tempat tinggalnya disebut sebagai Ruma Bolon, umumnya adalah Ruma yang terbesar dan memiliki ornamentasi ragam hias (Gorga) yang terlengkap.

Di belakang Ruma atau Sopo ada tempat kosong yang biasa dijadikan kebun. Sekeliling kampung dibentuk dengan tanah yang ditanami parik, sehingga berbentuk persegi panjang. Diatasnya ditanami pohon-pohon bambu. Pada ujung Barat dan Timur ada pintu gerbang (bahal). Di muka gerbang selalu ditanam pohon-pohon bertuah, seperti: pohon hariara, bintatar dan beringin (Napitupulu 1997).

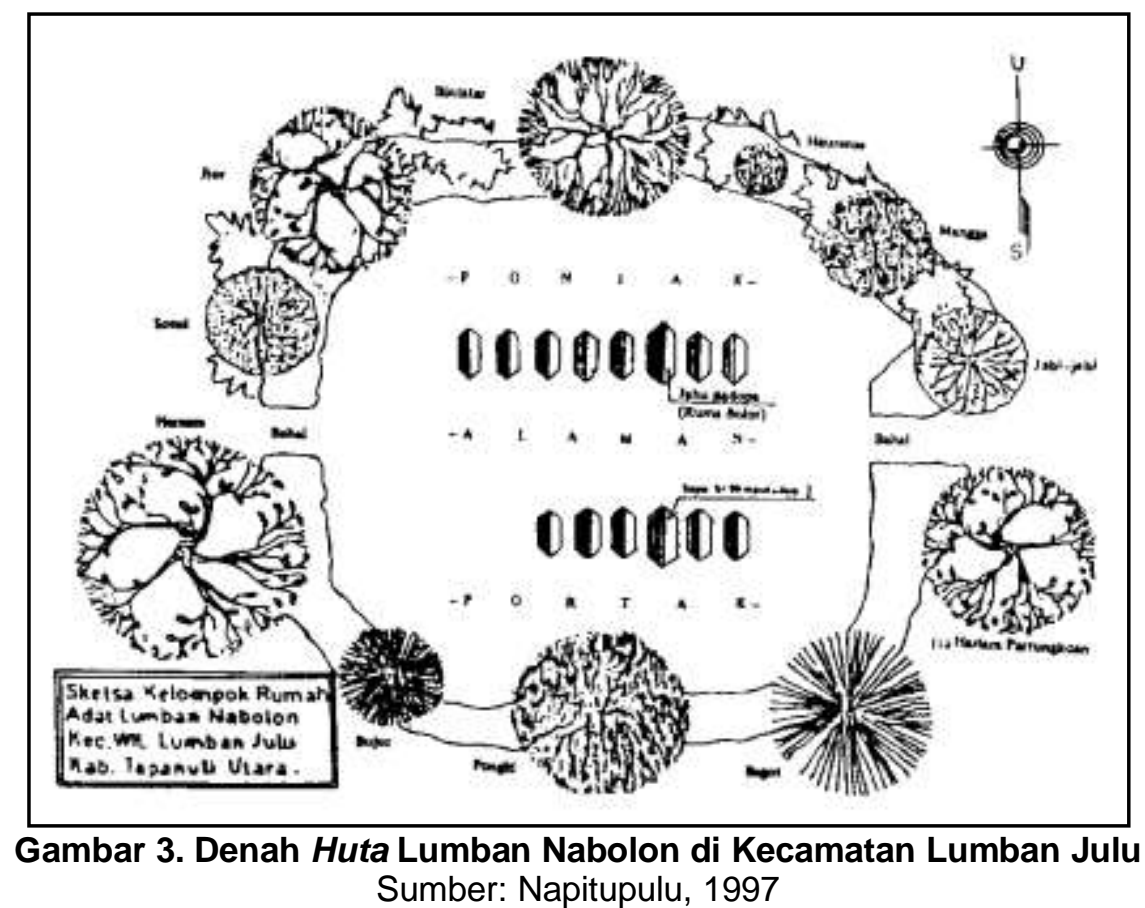

Ruma ada tiga jenis (Simamora 1997), yaitu: 1) Ruma Sitolumbea, rumah yang tangga dan pintunya berada di dalam. Tangga terletak antara tiang depan dan tiang dalam, sedangkan pintunya terdapat pada lantai. Disebut rumah yang berjenis kelamin betina, dan dianggap rumah yang paling lengkap. 2) Ruma Sisampuran atau Sibaba ni Amporik, rumah yang tangganya terdapat di muka tiang depan dan melekat pada ambang pintu, sedangkan pintu berada pada dinding muka. Disebut rumah yang berjenis kelamin jantan, karena tidak selengkap Ruma Sitolumbea. 3) Ruma Saru Angkola, rumah model baru yang sudah mengalami penyederhanaan tanpa pandindingan yang khas seperti kedua jenis rumah di atas. 

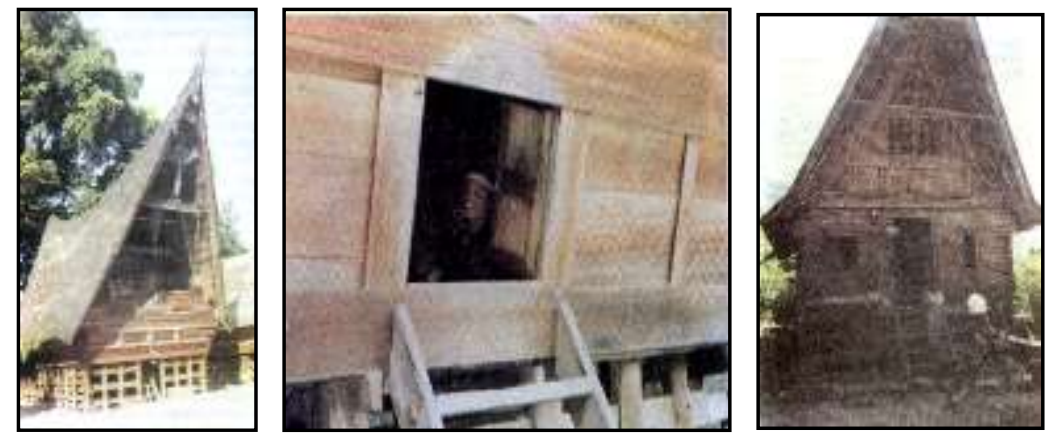

\section{Gambar 4. Ruma Sitolumbea, Ruma Sisampuran, Ruma Saru Angkola} Sumber: Simamora, 1997

Tiga partisi utama Ruma adalah kolong, interior dan atap. Kolong dibentuk oleh beberapa tiang dan pasak yang menghubungkannya. Kolong tidak berdinding, digunakan untuk tempat ternak piaraan (Simamora 1997).

Interior rumah terdiri atas satu ruang. Umumnya ruangan agak gelap karena jendela (padiloan) rumah cukup kecil. Tidak ada kamar-kamar yang dipisah oleh dinding. Secara umum ada ketentuan pembagian rumah pada masing-masing sudut, yaitu: Jabu Bona, Jabu Suhat, Jabu Soding dan Jabu Tampar Piring. Pembagian ini bukan dengan pembatasan dinding tetapi berdasarkan status kekeluargaan dari penghuni rumah. Ruangan tersebut berfungsi sebagai tempat tinggal dan tempat tidur, juga tempat perletakkan barang dan perkakas sehari-hari (Simamora 1997).

Atap adalah bagian atas ruang tempat tinggal. Pada bagian muka dan belakangnya terdapat balkon kecil. Antara balkon depan dan balkon belakang terdapat balok melintang yang besar, untuk menempatkan persembahan kepada roh nenek-moyang. Balkon sebelah depan biasanya digunakan untuk tempat pemusik gondang (pargonsi) mengiringi tarian (manortor) dalam ritual-ritual sakral, baik yang dilakukan di dalam maupun di luar rumah (Simamora 1997).

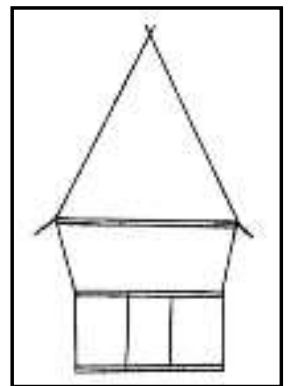

Gambar 5. Tampak depan, tampak samping kiri dan tampak atas Ruma Sumber: Simamora 1997

Tampak depan Ruma memperlihatkan ketiga partisi utama dengan jelas. Bagian bawah berbentuk bidang empat persegi panjang. Bagian tengah berbentuk trapesium terbalik. Bagian atas membentuk bidang segitiga sama kaki (Simamora 1997). Tampak samping tidak terlalu jauh berbeda dengan tampak depan, kecuali pada bagian atap. Bagian bawah membentuk bidang empat persegi panjang, bagian tengah membentuk bidang trapesium terbalik. Bagian atas membentuk pelana kuda. Sudut runcing bagian depan lebih 
menjorok panjang ke depan, tetapi sudut runcing bagian belakang lebih naik ke atas atau lebih tinggi (Simamora 1997). Tampak atas berbentuk bidang heksagonal (bidang bersegi enam) yang tidak sejajar. Bagian depan dan belakang membentuk bidang segitiga sama kaki, tetapi bagian depan lebih menjorok dari pada yang belakang. Bagian tengah membentuk bidang empat persegi panjang (Simamora 1997).

\section{Apropriasi Ruma Batak Toba Pada Bentuk Arsitektural Gereja Katolik Pangururan (GKP)}

Apropriasi dibahas berdasar elemen-elemen bentuk arsitektural Gereja Katolik Pangururan (GKP), meliputi: apropriasi pada wujud bangunan; ornamen ragam hias, posisi bangunan, dan orientasi bangunan.

\section{Apropriasi pada Wujud Bangunan}

Wujud dasar bangunan GKP adalah susunan tiga buah massa yang tersusun secara vertikal. Wujud tampak depan merupakan perpaduan tiga buah bentuk dasar, yaitu bidang empat persegi panjang (bagian bawah), bidang trapesium (bagian tengah) dan bidang segitiga (bagian atas).

Wujud tampak samping kanan tidak jauh berbeda dengan tampak depan, kecuali pada bagian atas. Bagian bawah membentuk bidang empat persegi panjang dan bagian tengah berbentuk bidang trapesium. Bidang bagian atas berbentuk pelana kuda. Sudut runcing bagian depan lebih menjorok panjang ke depan, sementara itu sudut runcing bagian belakang lebih naik keatas atau lebih tinggi.

Wujud tampak atas atau irisan atas menghasilkan bidang heksagonal (bidang bersegi enam) yang tidak sejajar. Bagian depan dan belakang membentuk bidang segitiga sama kaki, tetapi bagian depan lebih menjorok dari pada yang belakang. Bagian tengah membentuk bidang empat persegi panjang. Secara fungsi struktur bangunan, bidang bagian bawah berfungsi menjadi pondasi bangunan, bagian tengah berfungsi badan bangunan, bagian atas berfungsi sebagai atap bangunan.
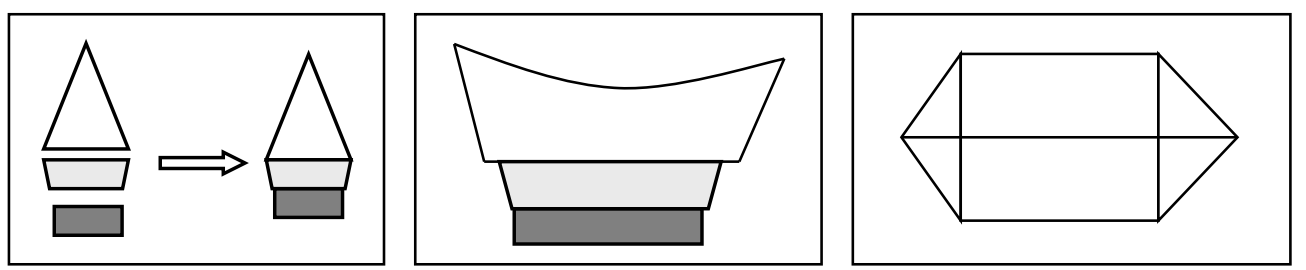

Gambar 6. Wujud GKP dari tampak depan, tampak samping kanan, dan tampak atas

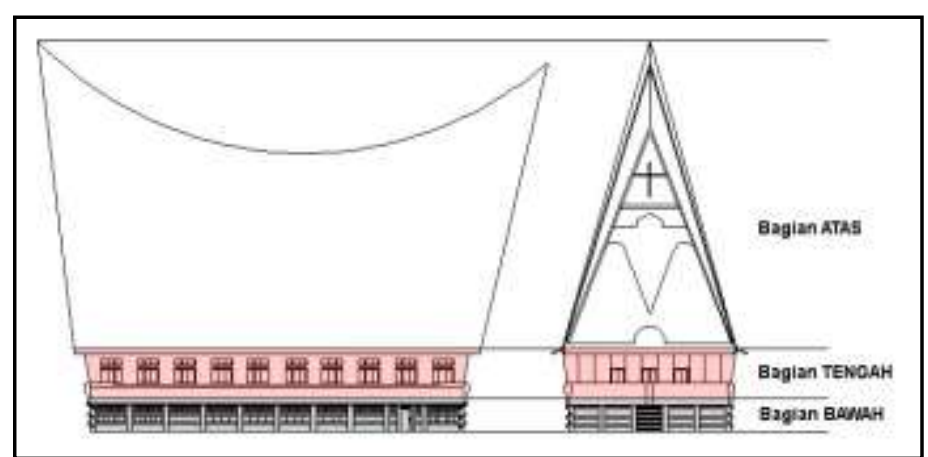

Gambar 7. Pola tingkatan massa bangunan pada Gereja Katolik Pangururan 
Apropriasi terjadi melalui proses adopsi konsep wujud dasar Ruma Batak Toba menjadi wujud dasar bangunan GKP (gambar 6). Yang membedakan hanyalah dari skala dimensi bangunannya. Ruma Batak Toba lebih skalanya lebih kecil dibanding bangunan GKP. Walau berdimensi lebih besar, tetap menyiratkan Ruma. Bukan dari sisi fisik bangunan saja, tetapi juga dari sisi psikologis yang dirasakan jemaat, seperti yang diungkapkan oleh Pastor Togar Herman Nainggolan (6 Mei 2011):

"Bangunan ini memang mirip Ruma Batak Toba, hanya lebih besar karena fungsinya untuk ibadah umat yang banyak, berkapasitas 700 orang. Bahkan konstruksinya dibuat mirip dengan Ruma Batak Toba, supaya jemaat merasa "feel at home" atau merasa gereja yang adalah Rumah Allah itu menjadi seperti rumah jemaat sendiri."

Konsekuensi dari wujud tersebut, pola tingkatan massa bangunan dari GKP (gambar 7) juga mengadopsi pola tiga tingkatan massa bangunan pada Ruma yang bernilai kosmologis. Tiga tingkatan yang menggambarkan dunia bawah, dunia tengah dan dunia atas juga diterapkan sebagai konsep pembagian zona vertikal pada GKP. Dunia bawah yang merupakan dunia kematian, diimplementasikan museum yang menyimpan artefakartefak masa lampau yang masih berbau animisme. Dunia tengah yang merupakan dunia kehidupan sekuler diimplementasikan sebagai ruang ibadah tempat misa berlangsung. Dunia atas yang merupakan dunia suci diimplementasikan sebagai ruang/balkon kosong (lihat tabel 1).

Tabel 1. Apropriasi konsep kosmologi Ruma pada Gereja Katolik Pangururan

\begin{tabular}{|c|c|c|}
\hline $\begin{array}{l}\text { Bagian } \\
\text { Bagunan }\end{array}$ & Ruma & Gereja Katolik Pangururan \\
\hline Bawah & $\begin{array}{l}\text { Bagian ini disebut banua toru (dunia } \\
\text { bawah). Dilambangkan dengan } \\
\text { kolong, dimaknai sebagai tempat } \\
\text { yang kotor, buruk, serta tempat } \\
\text { tinggal penguasa jahat dan kematian, } \\
\text { dewa Naga Padoha (Sibeth 1991; } \\
\text { Simamora 1997; Napitupulu 1997). }\end{array}$ & $\begin{array}{l}\text { Lantai dasar ini berfungsi sebagai ruang museum yang } \\
\text { menampilkan banyak artefak-artefak masa lalu yang } \\
\text { dianggap kafir. Maknanya, masa lalu yang dianggap } \\
\text { kafir itu sudah mati dan ditinggalkan. Jemaat Katolik } \\
\text { sudah mengalami "Lahir Baru", yaitu manusia yang } \\
\text { sudah meninggalkan dosa-dosa masa lalunya, berganti } \\
\text { menjadi seorang Katolik yang percaya pada Tuhan } \\
\text { Allah, dan Yesus Kristus sebagai juruslamatnya. }\end{array}$ \\
\hline Tengah & $\begin{array}{l}\text { Bagian ini disebut banua tonga } \\
\text { (dunia tengah). Dilambangkan } \\
\text { dengan lantai dan dinding, dimaknai } \\
\text { sebagai tempat tinggal manusia dan } \\
\text { segala mahluk hidup lainnya dalam } \\
\text { menjalani kehidupannya sehari-hari } \\
\text { (Sibeth 1991; Simamora 1997; } \\
\text { Napitupulu 1997). }\end{array}$ & $\begin{array}{l}\text { Bagian ini berfungsi sebagai ruang ibadah. Aktivitas } \\
\text { ibadah yang dijalani oleh jemaat merupakan ritual- } \\
\text { ritual simbolik bagi mereka dalam menjalani } \\
\text { kehidupan baru yang diperolehnya lewat proses "Lahir } \\
\text { Baru". }\end{array}$ \\
\hline Atas & $\begin{array}{l}\text { Bagian ini disebut banua ginjang } \\
\text { (dunia atas). Dilambangkan dengan } \\
\text { atap rumah, dimaknai sebagai tempat } \\
\text { yang sakral dan suci, tempat dewa } \\
\text { pencipta Mula Jadi Nabolon dan } \\
\text { dewata lainnnya (Sibeth 1991; } \\
\text { Simamora 1997; Napitupulu 1997). }\end{array}$ & $\begin{array}{l}\text { Bagian ini merupakan ruang kosong berupa balkon dan } \\
\text { atap, dimana balkon interior berfungsi sebagai ruang } \\
\text { ibadah, dan balkon eksterior berfungsi sebagai tempat } \\
\text { pemusik gondang sabangunan. Ruang kosong ini } \\
\text { ukurannya tinggi dan besar diatas skala manusia } \\
\text { umumnya. Maknanya menunjukkan kebesaran Tuhan } \\
\text { dan kecilnya manusia dibandingkan Tuhan. Hal ini } \\
\text { untuk mendorong agar jemaat tidak merasa sombong } \\
\text { dan tinggi hati, namun mengajarkan jemaat untuk } \\
\text { selalu tunduk pada ajaran Yang Besar dan Yang Maha } \\
\text { Tinggi, sebagai penguasa kehidupannya. }\end{array}$ \\
\hline
\end{tabular}




\section{Apropriasi pada Ornamen Ragam Hias}

Dari keempat bidang dinding yang melingkupi bangunan tersebut, yang menjadi center point arsitekturalnya adalah bidang bagian depan (tampak depan/fasad bangunan), dimana ornamen ragam hiasnya lebih banyak dan lebih penuh dibanding bidang yang lain. Ragam hias bertema kekristenan pada bagian depan (fasad) bangunan terdiri atas: ragam hias besar dan ragam hias kecil. Ragam hias besar antara lain: ornamen burung putih yang merupakan simbol Roh Kudus; ornamen salib yang distilasi merupakan simbol kekristenan; ornamen profil malaikat Santo Mikael yang berjuang membunuh naga (lambang setan dan dosa); ornamen piala dan roti yang merupakan simbol Sakramen Ekaristi; relief kisah Natal; relief empat kepala (manusia, singa, kerbau, burung) yang melambangkan empat Kitab Injil dalam Perjanjian Baru; serta ornamen patung Bunda Maria dengan tangan terbuka yang bermakna untuk menerima dan melayani setiap umat yang datang beribadah. Ragam hias kecil antara lain: ornamen lilin yang distilasi; ornamen Santo Fransiskus yang berkotbah pada burung dan hewan-hewan lainnya; ornamen burung membawa ranting zaitun sebagai lambang perdamaian Allah dengan manusia; ornamen domba dan salib yang melambangkan Yesus sebagai persembahan yang hidup; ornamen salib yang distilasi, merupakan simbol kekristenan; ornamen malaikat bersujud di hadapan roti kudus dan salib yang menggambarkan Sakramen Mahakudus; ornamen buku dan burung yang melambangkan Roh Allah bersama sabdaNya; ornamen A (Alfa) dan $\Omega$ (Omega), ornamen Anak Domba Allah; ornamen kisah mujizat Tuhan memberi makan 5000 orang dengan 5 roti dan 2 ikan; serta ornamen Santa Clara berjanji setia menjadi biarawati dihadapan Santo Fransiskus.

Ragam hias bertema kekristenan pada dinding kanan terdiri atas 22 (dua puluh dua) relief dari kisah Alkitab Perjanjian Lama, mulai dari kisah Allah menciptakan langit dan bumi beserta seluruh isinya hingga kisah pembangunan Bait Allah yang pertama oleh Raja Salomo. Alur membaca relief ini dari arah depan ke belakang. Ragam hias bertema kekristenan pada dinding kiri terdiri atas 21 (dua puluh satu) relief dari kisah Alkitab Perjanjian Baru, mulai dari kisah Maria menerima kabar sukacita dari malaikat hingga kisah kebangkitan Yesus Krsitus. Alur membacanya dari arah belakang ke depan.

Apropriasi pada ornamen ragam hias terjadi melalui proses adopsi bentuk ornamen gorga dari Ruma yang dipadukan dengan berbagai ragam hias bertema Kekristenan. Ornamen gorga yang diadopsi adalah ornamen singa-singa pada kedua sudut kanan dan kiri bagian depan, yang melambangkan kebenaran dan keadilan, namun ornamen ini telah ditambahkan dengan profil burung dan alkitab pada dahinya, sehingga ada perpaduan dengan kekristenan.

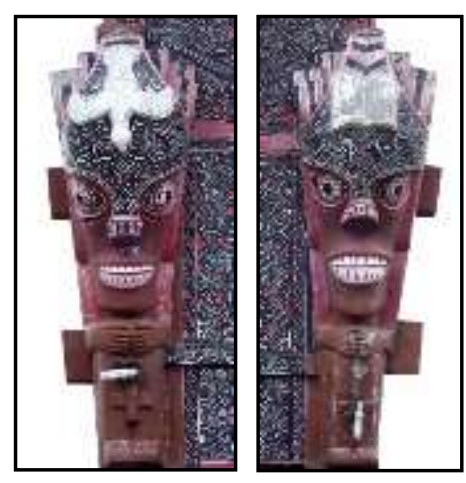

Gambar 8. Ornamen singa-singa pada fasad bangunan Gereja Katolik Pangururan 
Ragam hias gorga lain yang diadopsi juga adalah berbagai ragam hias flora/sulur-suluran, yang bermotif garis-garis spiral, berwarna merah, putih, hitam, seperti motif dalihan na tolu, desa na ualu, simatani ari, simeol-meol, dan silintong yang berfungsi sebagai ragam hias pengisi latar (background) yang tersebar hampir di seluruh bidang dinding eksterior bangunan.

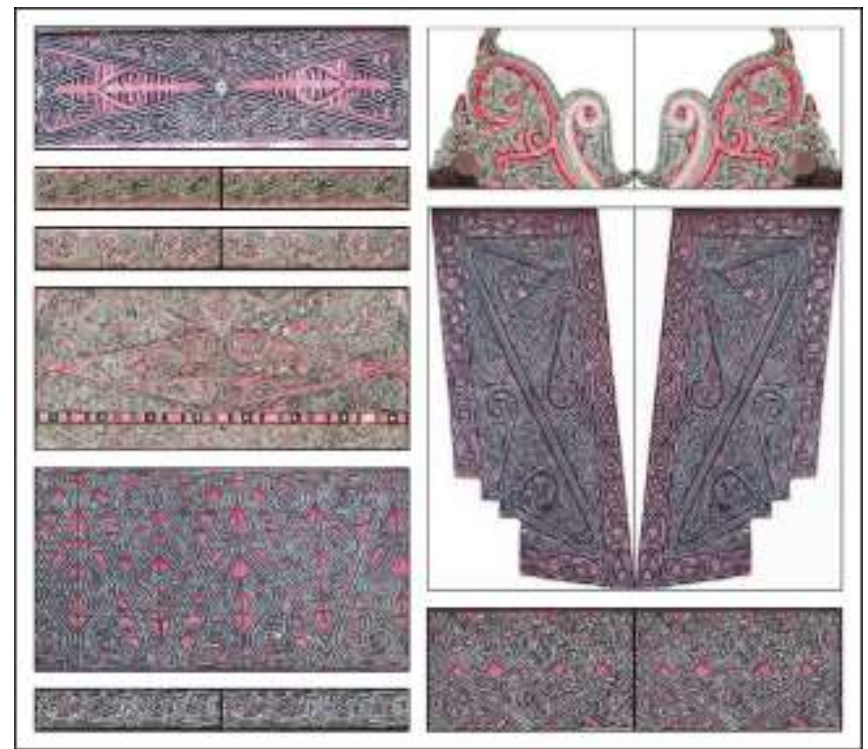

Gambar 9. Ragam hias gorga sulur-suluran pada dinding eksterior Gereja Katolik Pangururan

\section{Apropriasi pada Posisi Bangunan}

Posisi bangunan GKP merupakan bagian dari suatu kompleks bangunan yang disebut kompleks Paroki Pangururan. Bangunan berdiri tunggal, tidak bergandengan dengan bangunan lain. Saling berhadapan di seberangnya terdapat bangunan lain yang wujudnya hampir sama dengan bangunan GKP, namun dimensinya lebih kecil, serta tidak memiliki dinding. Oleh warga disebut Sopo. Kedua bangunan ini dihubungkan oleh sebuah halaman/lapangan, yang sehari-hari sering digunakan sebagai tempat bermain bagi anakanak sekitar gereja.

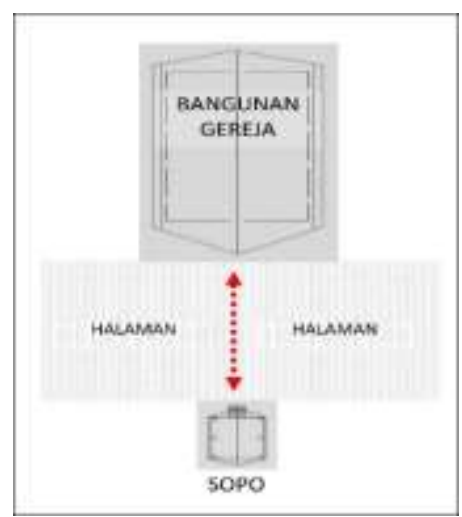

Gambar 10. Skema gereja dan sopo yang berhadapan tegak lurus dipisahkan oleh halaman [Halaman menjadi suatu bentuk ruang eksterior dalam konteks ruang arsitektur dari GKP] 
Apropriasi pada posisi bangunan terjadi lewat proses adopsi konsep posisi bangunan dari Ruma pada sebuah Huta (kampung tradisional Batak Toba), dimana didepan Ruma terdapat bangunan Sopo yang dipisahkan dengan halaman, yang membentuk posisi RumaAlaman-Sopo. Halaman menjadi ruang eksterior yang bersifat profan, dan interior gereja (tempat misa) menjadi ruang sakral. Hal ini serupa dengan konsep Ruma-alaman pada konsep huta, dimana Ruma bermakna sakral dan alaman bermakna profan, tempat berlangsungnya aktivitas-aktivitas sosial dan umum.

\section{Apropriasi pada Orientasi Bangunan}

Bangunan gereja ini adalah bangunan baru, sedangkan bangunan gereja lama berada di area terpisah dengan orientasi bangunan ke arah Timur atau ke Jalan Soegiyopranoto. Bangunan GKP yang sekarang memiliki orientasi bangunan menghadap ke arah Barat atau ke arah jalan Putri Lopian, danau Toba dan pegunungan Pusuk Buhit yang mengelilingi danau itu.

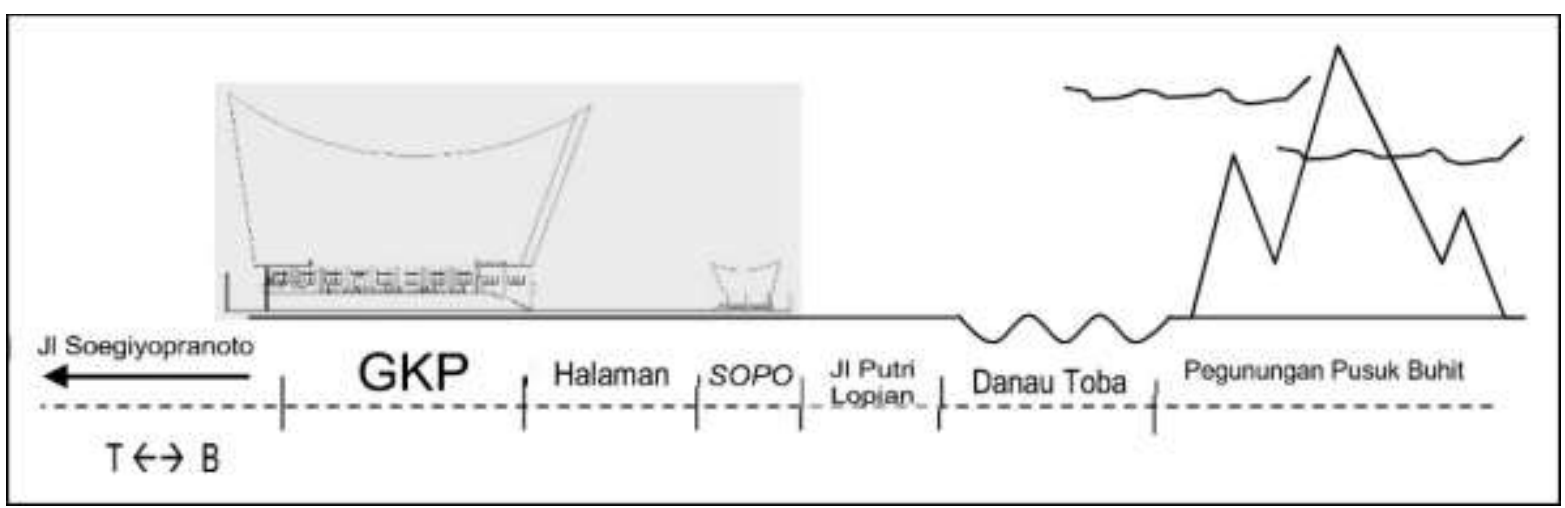

Gambar 11. Orientasi bangunan gereja yang transenden pada pegunungan Pusuk Buhit dan danau Toba

Apropriasi terjadi lewat proses adopsi konsep orientasi bangunan dari Ruma Batak Toba terutama Ruma Bolon, yang orientasi bangunannya menghadap pada pegungunan Pusuk Buhit dan danau Toba. Dalam pandangan masyarakat tradisional Batak Toba, Pusuk Buhit dan danau Toba adalah tempat-tempat yang disakralkan dan dikuduskan dalam legenda-legenda orang Batak kuno, karena Pusuk Buhit dianggap sebagai tempat bersemayamnya penguasa dunia. Sedangkan danau Toba dianggap sebagai pemberi kehidupan, karena dari danau inilah sumber penghidupan utama masyarakat Batak zaman itu. Hal ini menunjukan konsep orientasi bangunan yang mirip dengan orientasi kosmologi Ruma Batak Toba, yang transenden terhadap Pusuk Buhit dan danau Toba.

Apropriasi budaya Batak Toba yang dilakukan oleh Gereja Katolik Pangururan (GKP) adalah dengan cara mengadopsi konsep-konsep arsitektural Ruma Batak Toba. Simpulan ini sejalan dengan yang diungkapkan oleh Pastor Togar Herman Nainggolan (6 Mei 2011):

Makna keberadaan gereja dimaksudkan supaya orang di sekitarnya dalam berbagai aktivitasnya dilakukan bersama-sama dengan Allah dan komunitas seimannya. Berkumpul, berdoa, memuji bersama, sama seperti saudara satu keluarga yang bersama-sama memuji Allah. Seperti Ruma Batak Toba, berperan sebagai tempat berkumpul saudara-bersaudara sebagai sebuah keluarga besar, 
seperti itulah pulalah bangunan gereja ini berperan sebagai Rumah Allah, dimana jemaat-jemaat itu menjadi satu keluarga besar pula.

\section{Simpulan}

Adopsi konsep-konsep arsitektural Ruma Batak Toba merupakan apropriasi budaya Batak Toba yang dilakukan oleh Gereja Katolik Pangururan (GKP). Wujud apropriasi terlihat pada bentuk arsitektural GKP, meliputi wujud bangunan, ornamen ragam hias, posisi bangunan dan orientasi bangunan. Apropriasi yang diterapkan oleh gereja Katolik ini menghasilkan sebuah arsitektur gereja yang sangat menyatu dengan budaya lokal dimana gereja berada. Bentuk arsitektur gereja yang ada lebih menyerupai rumah tradisional Batak Toba dibandingkan menyerupai bentuk gereja Katolik umumnya yang bergaya gotik. Hal ini merupakan dampak dari politik gereja Katolik melalui melalui "Konsili Vatikan II: Dekrit tentang Kegiatan Misioner Gereja". Dalam dokumen dekrit tersebut, terdapat pasal-pasal yang mendorong lahirnya gereja-gereja Katolik lokal, yaitu gereja Katolik yang berciri budaya lokal dimana gereja Katolik itu berada. Proses apropriasi ini telah memperkaya budaya gereja Katolik tetapi juga memberi warna baru bagi perkembangan budaya Batak Toba. Dalam hal ini proses apropriasi telah memberi keuntungan bagi kedua budaya yang bertemu.

\section{Daftar Pustaka}

Abdurrahman DI (2018) Apropriasi Transkultural Pada Konfigurasi Karakter Son Goku Dalam Manga Dragon Ball. Idealogy 3 (2): 1-12. http://idealogyjournal.com/ojs/index.php/idealogy/article/view/52/39.

Ad Gentes: Decree on The Mission Activity of The Church (Accesed 19 Maret 2011) http://www.vatican.va/archive/hist_councils//ii_vatican_council/documents/vatii_decree_19651207_ad-gentes_en.html).

Barendregt B \& Els B (2016) Merenungkan Gema Perjumpaan Musikal IndonesiaBelanda. Jakarta: Yayasan Obor Indonesia.

Budrianto, Wilma S \& Marta R (2018) Aproprasi Gitar dalam Kesenian Rejung pada Masyarakat Suku Bashemah Kabupaten Kaur Provinsi Bengkulu. Gorga Jurnal Seni Rupa Vol 7 (2): 94-100. https://doi.org/10.24114/gr.v7i2.10915.

Napitupulu SP ((1997) Arsitektur Tradisional Daerah Sumatera Utara. Jakarta: Departemen Pendidikan dan Kebudayaan.

Prier KE (1999) Inkulturasi Musik Liturgi. Yogyakarta: Pusat Musik Liturgi.

Rogers RA (2006) From Cultural Exchange to Transculturation: A Review and Reconceptualization of Cultural Appropriation. Communication Theory 16: 474503. https://doi.org/10.1111/j.1468-2885.2006.00277.x.

Sibeth A (1991) The Batak: Peoples of the Island of Sumatra. London: Thames \& Hudson. 
Simamora T (1997) Rumah Batak Toba: Usaha Inkulturatif. Pematangsiantar.

van den End Th \& J Weitjens (2000) Ragi Carita: Sejarah Gereja di Indonesia 2 (1860ansekarang). Jakarta: BPK Gunung Mulia.

Walker HS (1998) Indigenous or Foreign?: A Look ath the Origins of the Monkey Hero Sun Wukong. Sino-Platonic Papers, Number 81. Philadelphia: Department of East Asian Languages and Civilizations, University of Pennsylvania.

Young JO (2010) Cultural Appropriation and the Arts. John Wiley \& Sons Ltd. 